\title{
Imiquimod como Tratamento Neoadjuvante Antes da Cirurgia na Doença de Paget Extramamária
}

\author{
Costa-Silva $M^{1}$, Costa $\mathrm{MA}^{2}$, Costa JS ${ }^{3}$, Azevedo F ${ }^{4}$, Lisboa C, ${ }^{5}$ \\ 'Interno do Internato Complementar de Dermatologia e Venereologia/Resident, Dermatology and Venereology, Centro Hospitalar \\ São João, EPE, Porto, Portugal \\ 2Professora Doutora, Especialista em Ginecologia e Obstetrícia/ Professor, Consultant of Gynecology, Centro Hospitalar São João, \\ EPE, Porto, Portugal; Departamento da Mulher e da Criança, Faculdade de Medicina da Universidade do Porto, Portugal \\ ${ }^{3}$ Especialista em Cirurgia Plástica/ Consultant of Plastic Surgery, Centro Hospitalar São João, EPE, Porto, Portugal \\ ${ }^{4}$ Diretora do Serviço de Dermatologia e Venereologia/Head of the Dermatology and Venereology Department, Centro Hospitalar \\ São João, EPE, Porto, Portugal \\ ${ }^{5}$ Professora Doutora, Especialista em Dermatologia e Venereologia/Professor, Consultant of Dermatology and Venereology, Centro \\ Hospitalar São João, EPE, Porto, Portugal; Serviço de Microbiologia, Faculdade de Medicina do Porto, Porto, Portugal
}

RESUMO - A doença de Paget extramamária (DPEM) é uma neoplasia maligna cutânea, rara, observada principalmente em mulheres caucasianas pós-menopausa. A cirurgia é o tratamento mais comum. No entanto, no que diz respeito à DPEM vulvar, o seu tratamento cirúrgico passa frequentemente por cirurgia radical, que pode ser mutilante e levar à perda de feminilidade. Recentes avanços terapêuticos têm incluído abordagem médica e multimodal médico-cirúrgico, permitindo uma maior preservação da anatomia genital e subsequente diminuição da morbilidade. Neste sentido, imiquimod tem sido utilizado, off-label, como monoterapia ou terapêutica adjuvante na DPEM.

Relatamos o caso de uma mulher com DPEM extenso na área anogenital submetida a resseção cirúrgica complementada com reconstrução plástica e precedida de tratamento médico com imiquimod. $O$ imiquimod neoadjuvante permitiu uma citorredução significativa da área tumoral, minimizando a radicalidade cirúrgica, mantendo a função local e a morfologia.

PALAVRAS-CHAVE - Doença de Paget Extramamária/tratamento; Imiquimod; Neoplasias da Vulva/tratamento; Terapia Neoadjuvante.

\section{Neoadjuvant use of Imiquimod Before Surgery in Extramammary Paget's Disease}

ABSTRACT - Extramammary Paget's disease (EMPD) is a distinct form of a rare malignant skin neoplasm, primarily seen in postmenopausal Caucasian women. Surgery is the most common treatment. However, concerning vulvar EMPD, radical surgery can be mutilating and leads to loss of femininity. Recent therapeutic development has included medical and medical-surgical approaches, allowing better preservation of genital anatomy with subsequent reduced morbidity. Accordingly, off-label use of imiquimod has been reported as a monotherapy or adjuvant therapy in EMPD.

We report the case of a woman with extensive EMPD in the anogenital area, submitted to surgical resection complemented with plastic reconstruction and preceded by imiquimod medical treatment. Neoadjuvant imiquimod induced a significant cytoreduction of the tumor area, minimizing surgical radicality and maintaining local function and morphology

KEYWORDS - Imiquimod; Neoadjuvant Therapy; Paget Disease, Extramammary/therapy; Vulvar.

Correspondência: Miguel Costa e Silva

Department of Dermatology and Venereology, Centro Hospitalar São João

Alameda Prof. Hernâni Monteiro, 4200-319 Porto

Phone number: +351225512193

Fax number: +351225025766

Email: miguelcostaesilva.dermato@gmail.com

DOI: https://dx.doi.org/10.29021/spdv.76.2.901
Recebido/Received

07 Fevereiro/February 2018

Aceite/Accepted

17 Março/March 2018 


\section{Caso Clínico}

\section{INTRODUCTION}

Extramammary Paget's disease (EMPD) is a distinct form of a rare malignant skin neoplasm, an intraepithelial neoplasia of glandular cells, ${ }^{1}$ first reported by Crocker $^{2}$ in 1889 in the scrotum and penis. Vulvar Paget's disease was first reported in 1901 by Dubreuilh. ${ }^{3}$ EMPD is primarily seen in postmenopausal Caucasian women and the most common site of involvement is the vulva, where it represents less than $1 \%$ of the vulvar malignancies and is rarely invasive $(<10 \%) .{ }^{4}$ It typically appears as erythematous, scaly or moist, eczematous lesions with irregular borders, accompanied by pruritus. ${ }^{1}$ Vulvar Paget's disease often spreads in an occult fashion extending beyond the clinically apparent edges of the lesion. ${ }^{4}$ These patients are at risk for a second synchronous or metachronous neoplasm, namely, colorectal adenocarcinoma, adenocarcinoma of the cervix, carcinoma of the transitional epithelium from the renal pelvis to the urethra, breast and vulvar carcinoma. ${ }^{5,6}$ Staging should include examination of the entire cutaneous integument, evaluation of draining lymph nodes and exclusion of genitourinary and colorectal malignant tumors. ${ }^{5,7}$ Recent therapeutic modalities have emerged. Surgery, by default, is the most common treatment, but it is challenging to excise the disease adequately, and recurrence is common, leading to repeated surgical procedures and mutilation. ${ }^{4}$ The use of neoadjuvant therapies prior to surgery has been performed in many neoplasias, allowing tumor cytoreduction, making subsequent surgical excision easier. ${ }^{8}$ We report a case of a woman with extensive EMPD in the anogenital area treated with neoadjuvant imiquimod before excisional and reconstructive surgery.

\section{CASE REPORT}

A 67-year-old woman was referred for evaluation of a pruritic, anogenital lesion, resistant to topical antifungals and corticosteroids with months of evolution. Her medical history included an infiltrating ductal carcinoma of the breast 17 years before, submitted to left mastectomy, radiotherapy and hormone therapy. Physical examination revealed a $16 \times 7 \mathrm{~cm}$ large, erythematous, scaly plaque with irregular but well demarcated borders, centered by small erosions, localized in the genital and perianal areas (Fig. 1). No inguinal adenopathies or extragenital cutaneous lesions were found. Histopathology

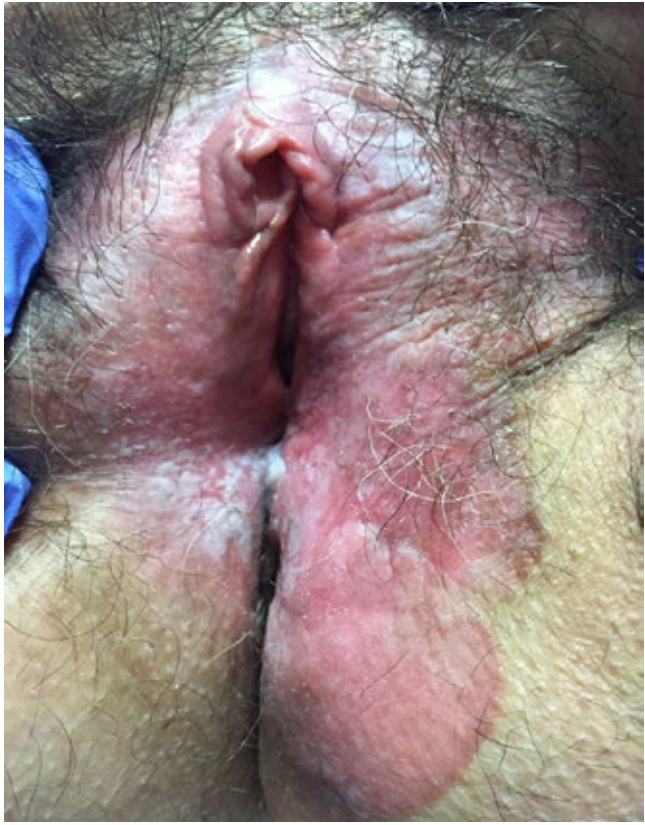

Figure 1

showed cells with large abundant pale-staining cytoplasm and large nuclei, with prominent nucleoli infiltrating the epidermis without dermal invasion (Fig. 2a-b). It was immunopositive for CK7, CEA, GCDFP-15, CAM5. ${ }^{2}$ and EMA, and negative for S-100 and CK20. Thorough gynecological evaluation, thoraco-abdomino-pelvic computed tomography, pelvic magnetic resonance, proctoscopy and cystoscopy excluded synchronous malignancies. Laboratory evaluations were unremarkable except for syphilis serology, which reveled late latent syphilis promptly treated with benzathine penicillin $G 2,4$ million units weekly, 3 doses.

The diagnosis of primary intraepithelial EMPD was confirmed. To achieve tumor reduction before surgery patient was treated with imiquimod 5\% cream, 3 times per week, for 12 weeks with partial response. To maximize the clinical response, it was increased to daily application, but was stopped 5 weeks later due to systemic symptoms (anorexia, headache

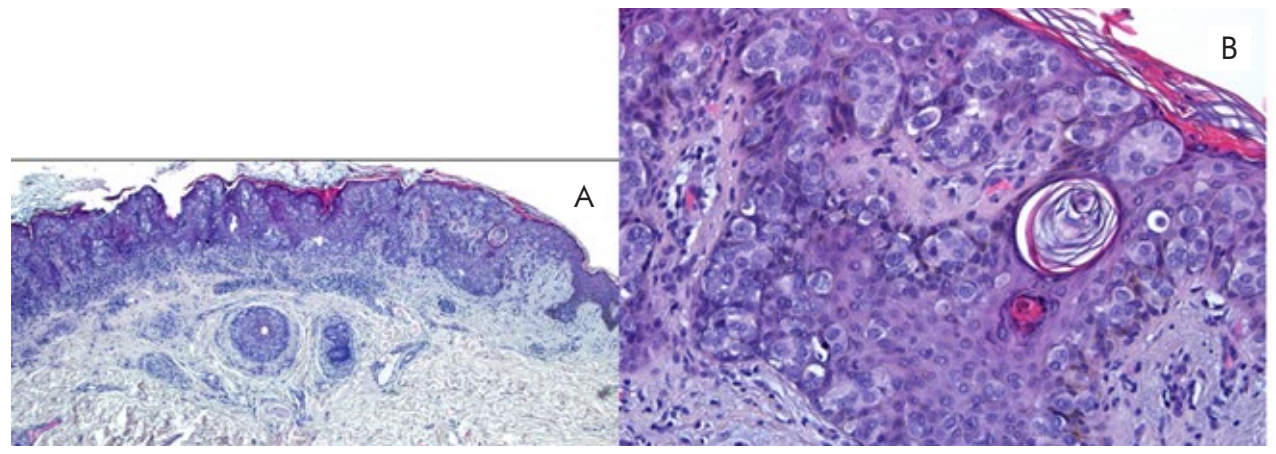

Figure 2 


\section{Caso Clínico}

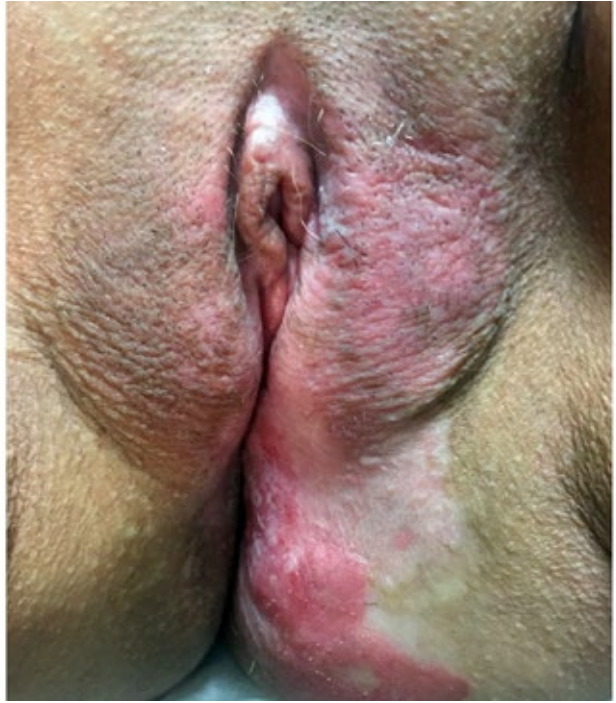

Figure 3

and dizziness). At this point substantial tumor reduction was seen (Fig. 3) and patient underwent partial bilateral vulvectomy with V-Y fasciocutaneous flap reconstruction (Fig. 4). Histopathology revealed Paget's disease involvement of the surgical margins at the right labia majora of the vulva. A relapse was seen after one year of follow-up (Fig. 5). The patient restarted imiquimod application 3 times per week, while awaiting surgical reintervention.

\section{DISCUSSION}

EMPD lesions are generally confined to the epidermis, but it can invade the dermis and metastasize to regional lymph nodes or distant organs. ${ }^{9}$ Mohs micrographic surgery or wide local excision are the traditional therapeutic options. ${ }^{10,11}$ Recently, a safe resection margin of $2 \mathrm{~cm}$ has been recommended. ${ }^{10,11}$

EMPD lesions commonly develop in apocrine-rich areas such as the vulva, penis, scrotum, perianal, and axilla, consequently, tissue loss and functional impairment after surgery are associated with significant morbidities. ${ }^{10,12}$ Concerning vulvar EMPD, is very important to avoid the long-term complications of radical surgery, such as pain and scarring, a feeling of mutilation, loss of femininity and also, adverse impact on sexual function. ${ }^{4}$ Actually, surgeons face a huge challenge: balance between potentially extensive radical surgery (which allows free surgical margins reducing theoretically the relapse) versus conservative surgery (which preserves genital anatomy and function). ${ }^{10}$ Furthermore, indistinct borders, subclinical extensions and multifocal nature associated with EMPD result in high recurrence rates despite adequate surgical resection margins. ${ }^{10,13}$ In 2013, Edey et $\mathrm{a}^{4}$ published a Cochrane review evaluating the different treatment modalities for vulvar Paget's disease. They found that most studies stated that margin status had no impact on recurrence. Similarly, a recent review of 89 cases of vulvar Paget's disease by Onaiwu et a ${ }^{5}$ found no association between margin status and recurrence rates. Given the

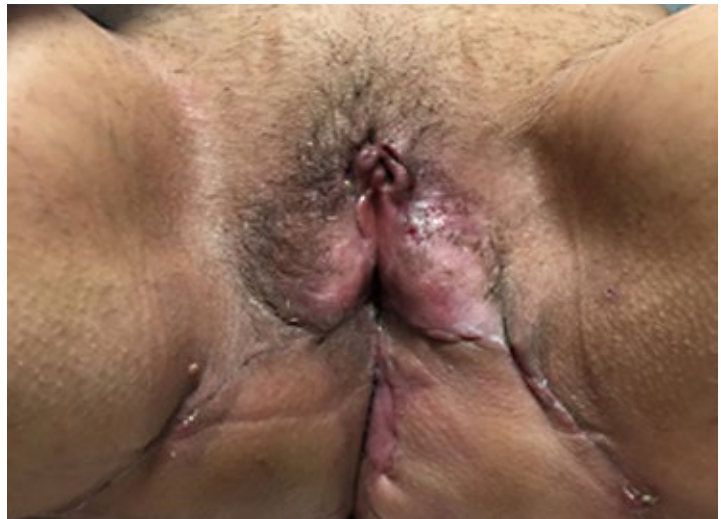

Figure 4

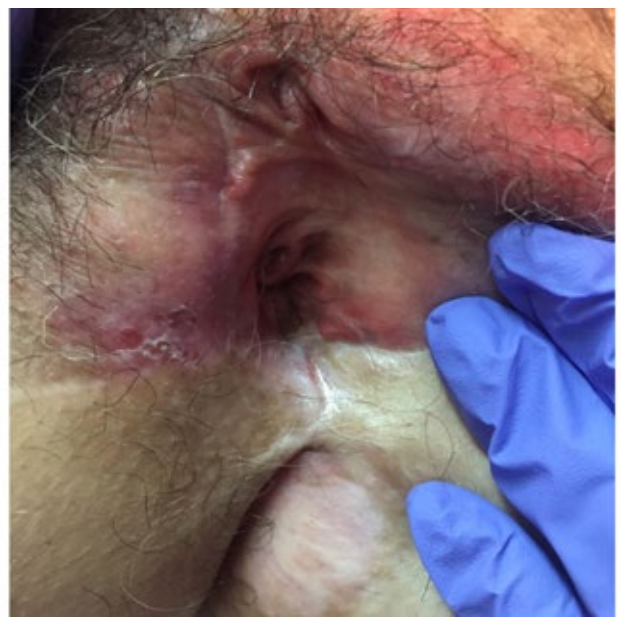

Figure 5

potential negative sequelae and the high rate of recurrence, a more conservative approach may be of benefit when there is no evidence of an underlying adenocarcinoma. ${ }^{14}$

Generally, EMPD appears as carcinoma in situ and has a favorable prognosis. However, in about $20 \%$ of cases EMPD progresses to an invasive tumor, invasive EMPD (iEMPD), which can metastasize mainly through the lymphatic channels and become fatal. ${ }^{15}$ A TNM evaluation has been recently proposed by Ohara et al. ${ }^{15}$

Other treatment options include topical imiquimod, topical 5-fluorouracil, topical bleomycin sulfate, intralesional interferon- $\alpha$, radiation therapy, cryotherapy, chemotherapy, laser ablation and photodynamic therapy., 80 Imiquimod is a biological response modifier, which stimulates both innate and acquired immune function resulting in potent antiviral, antitumor and immunoregulatory properties. ${ }^{1,12}$ After Zampogna et al publication of 2 cases of primary limited cutaneous perineal and genital EMPD treated with imiquimod 5\%,16 off-label use has been successfully reported as a monotherapy or adjuvant therapy in EMPD. ${ }^{1,8,9,10,12,14}$ A recent systematic review reported a response rate to imiquimod ranging from $50 \%$ to $80 \%$ with

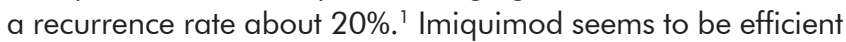


also in cases of EMPD recurrence and was reported as an interesting neodjuvant treatment before surgery by Toledo et al, ${ }^{8}$ to reduce tumor size before surgery. However, there are also reports of failure after imiquimod treatment in EMPD. ${ }^{17}$ The optimal frequency and length of treatment time remains to be defined. ' The intensity of imiquimod's effect is dose-dependent and so the probability of local and systemic side effects is increased with daily application, as experienced by our patient. ${ }^{12}$

Our patient presented with an extensive EMPD affecting a great part of the anogenital region. The neoadjuvant treatment with imiquimod $5 \%$ cream, induced a significant chemical cytoreduction of the tumoral area (histologically confirmed after the excision once the periphery of the lesion was free of neoplasia except at one location) allowing a later surgical excision of an otherwise inoperable/highly mutilating neoplasm. In addition to the clinical reduction of the tumor area after treatment with imiquimod, histopathology revealed a complete response in the margins except for one area.

\section{CONCLUSION}

Immune modulators, such as imiquimod, can be a good alternative as a neoadjuvant treatment previous to surgery in selected cases of extensive EMPD. Promising results have been published recently in the literature validating the need for well-designed clinical trials.

Conflitos de interesse: Os autores declaram não possuir conflitos de interesse.

Suporte financeiro: $O$ presente trabalho não foi suportado por nenhum subsídio ou bolsa.

Confidencialidade dos dados: Os autores declaram ter seguido os protocolos do seu centro de trabalho acerca da publicação dos dados de doentes.

Protecção de pessoas e animais: Os autores declaram que os procedimentos seguidos estavam de acordo com os regulamentos estabelecidos pelos responsáveis da Comissão de lnvestigação Clínica e Ética e de acordo com a Declaração de Helsínquia da Associação Médica Mundial

Conflicts of interest: The authors have no conflicts of interest to declare.

Financing Support: This work has not received any contribution, grant or scholarship.

Confidentiality of data: The authors declare that they have followed the protocols of their work center on the publication of data from patients.

Protection of human and animal subjects: The authors declare that the procedures followed were in accordance with the regulations of the relevant clinical research ethics committee and with those of the Code of Ethics of the World Medical Association (Declaration of Helsinki).

\section{REFERENCES}

1. Machida H, Moeini A, Roman LD, Matsuo K. Effects of imiquimod on vulvar Paget's disease: a systematic review of literature. Gynecol Oncol. 2015;139:165-71.

2. Crocker HR. Paget's disease, affecting the scrotum and penis. Trans Pathol. Soc Lond. 1889; 40:187-91.

3. Dubreuilh W. Paget's disease of the vulva. Br J Dermatol. 1901;13:403-13.

4. Edey KA, Allan E, Murdoch JB, Cooper S, Bryant A. Interventions for the treatment of Paget's disease of the vulva. Cochrane Database Syst Rev. 2013; 26:CD009245.

5. Onaiwu CO, Salcedo MP, Pessini SA, Munsell MF, Euscher EE, Reed KE, et al. Paget's disease of the vulva: A review of 89 cases. Gynecol Oncol Rep. 2016;30;19:469.

6. Preti $M$, Micheletti L, Ghiringhello B, Privitera S, Condello V, Chieppa P, et al. La malattia di Paget vulvare. Revisione clinico-patologica della letteratura. Minerva Ginecol. 2000;52:203-11.

7. Tebes S, Cardosi R, Hoffman M. Paget's disease of the vulva. Am J Obstet Gynecol. 2002;187:281-3.

8. Toledo F, Silvestre JF, Cuesta L, Ballester I, Latorre N, Monteagudo A. Sequential use with imiquimod and surgery in extramammary Paget's disease. Dermatol Ther. 2012;25:82-5.

9. Koh YX, Tay TK, Xu S, Lee CM, Teo MC. A clinical series and literature review of the management of inguinal nodal metastases in patients with primary extramammary Paget disease of the scrotum. Asian J Surg. 2015;38:406.

10. Choi JH, Jue MS, Kim EJ, Joh OJ, Song KY, Park HJ. Extramammary Paget disease: minimal surgical therapy. Ann Dermatol. 2013;25:213-7.

11. Murata Y, Kumano K. Extramammary Paget's disease of the genitalia with clinically clear margins can be adequately resected with $1 \mathrm{~cm}$ margin. Eur J Dermatol 2005; 15:168-70.

12. Liau MM, Yang SS, Tan KB, Aw CW. Topical imiquimod in the treatment ofextramammary Paget's disease: A 10 year retrospective analysis in an Asian tertiary centre. Dermatol Ther. 2016;29:459-62.

13. Yang WJ, Kim DS, Im YJ, Cho KS, Rha KH, et al. Extramammary Paget's disease of penis and scrotum. Urology 2005;65:972-5.

14. Cowan RA, Black DR, Hoang LN, Park KJ, Soslow RA, Backes FJ, et al. A pilot study of topical imiquimod therapy for the treatment of recurrent extramammary Paget's disease. Gynecol Oncol. 2016;142:139-43.

15. Ohara K, Fujisawa Y, Yoshino K, Kiyohara Y, Kadono T, Murata $Y$, et al. A proposal for a TNM staging system for extramammary Paget disease: Retrospective analysis of 301 patients with invasive primary tumors. J Dermatol Sci. 2016;83:234-9.

16. Zampogna JC, Flowers FP, Roth WI, Hassenein AM. Treatment of primary limited cutaneous extramammary Paget's disease with topical imiquimod monotherapy: two case reports. J Am Acad Dermatol 2002;47(Suppl 4):S229-35.

17. Jim On SC, Izumi AK. Extramammary Paget disease: failure to respond to topical imiquimod 5\%. J Am Acad Dermatol. $2011 ; 65: 656-7$. 